\title{
The Features of the System of Normative-Legal Acts of Local Self-Government of Ukraine: A Rejection of the Soviet Union Postulates in Favour of the European Union Values
}

Oleh Petryshyn

Scientific Research Institute of State Building and Local Government of the National Academy of Legal Sciences of Ukraine

Chernyshevska 80

Kharkiv 61002, Ukraine E-mail: ndi_db_ms@ukr.net

Maryna Petryshyna

Yaroslav Mudryi National Law University

Pushkinska 77,

Kharkiv 61024, Ukraine

E-mail: marynaoleksa@gmail.com

Oleh Hyliaka

National Academy of Legal Sciences of Ukraine
Pushkinska 70,
Kharkiv 61024, Ukraine
E-mail: aprnu@ukr.net

Taras Didych

Taras Shevchenko National University of Kyiv

Volodymyrska, 60 ,

Kyiv 01033, Ukraine

E-mail: tarasdid@ukr.net

Abstract: In this article, the authors, collaboratively and based on their experience of related research (normative-legal activity of local selfgovernment (Petryshyna, 2011), general theoretical problems of lawmaking and norm-making (Didych, 2018), problems of reception of foreign experience of reforming local self-government (Petryshyn, 
2014), and pressing problems of decentralization reform (Hyliaka, 2015)) investigate the features and the shortcomings of the system of normative-legal acts of local self-government of Ukraine. These include: the problems of the legal status and the nature of the modern system of normative legal acts of local self-government, its normative-legal consolidation; the issues of practical law-making by bodies and officials of local self-government through the prism of the heritage of the Soviet system of local self-government; the shortcomings in the reforms undertaken since independence; the ongoing decentralization and associated reforms as well as existing concepts and plans aimed at the integration of Ukraine into European legal space and the European Union in particular.

The result of the study was the identification of a number of substantiated features of the system and general recommendations aimed at the improvement of the overall state of local self-government and its law-making activity in the context of the current and future related reforms in Ukraine.

Keywords: law-making, legislative system, local self-government, normativelegal acts of local self-government, rulemaking

\section{Introduction}

The peculiarities of the formation of a system of normative-legal acts of local self-government are determined by the nature and peculiarities of the formation of the national system of legislation of Ukraine. Today, an important role in this process is played by such preconditions and factors as the transitional period of development of the state and society, manifested in the gradual departure from the outdated guidelines and postulates, the adoption of various concepts and strategies of state and legal development as an attempt to determine the direction of further development of the state in the world, as well as the consistent implementation of the action plan for accession to the European Union, which, among other things, envisages adaptation of domestic legislation to the legislation of the European Community.

The challenges that Ukraine faces today are largely due to the fact that during the years of independence the state failed to form strong local self-government that would effectively resolve issues of local importance. 
Although the need for local self-government reform has been discussed for over 15 years, attempts to implement it have not yet been successful. At the same time, decentralization is no longer just a desire to improve public administration at all levels, but a necessary prerequisite to overcome the political crisis in Ukraine. After all, the existing system of local self-government in terms of efficiency and effectiveness of exercising the powers is far behind the requirements of modernity and standards adopted in the Member States of the European Union, which affect the quality of its functions and management of public services to the local residents.

Nevertheless, apart from delegating certain powers that are, sometimes, burdensome for some local self-government bodies, as well as carrying out nationwide, but not always conscious, enlargement (amalgamation) of local communities, it is now difficult to talk about the uniquely positive results of the decentralization reform in Ukraine. In addition, it should be borne in mind that the movement towards achieving the goals of the reform is not progressive, in particular, taking into account the fact that, following the approval of the Concept of reforming of local self-government and territorial organization of administration in Ukraine, conceptual changes in the constitutional and legal regulation of these questions have not yet taken place (Order of the Cabinet of Ministers of Ukraine, no. 333-p). Regardless of what has been mentioned above, the measures planned by the Ukrainian authorities and announced by politicians and statesmen including the revision of the relevant positions of the Constitution and the Law of Ukraine 'On local self-government in Ukraine' should be noted positively.

In our opinion, the named factors are the most critical in the construction of the structure of national legislation of Ukraine. Indeed, many leading experts reiterate the idea that the current Ukrainian legislation system leaves much to be desired and calls for improvement. Based on the analysis of recent research in this area, it can be argued that the adoption of new legislative acts, as well as further adaptation, harmonization, unification, and systematization of the legislation, can contribute to the solution of the problem.

Thus, the subject of this research is the system of normative-legal acts of local self-government. The purpose of this article is to identify the features of the system of normative-legal acts of local self-government. To achieve this goal it is necessary to solve the following problems: (1) to determine the extent that the problem has been explored; (2) to determine the state of theoretical and methodological development of a number of basic components of the study, such as 'system of law', 'system of legislation', 'local self-government', 'municipal 
power', etc.; (3) to characterize the acts, including regulatory legal acts of local self-government; and (4) to determine the place and role of acts of local selfgovernment in the system of national legislation.

\section{The current state of the problem research}

Dovzhenko (2014) believes that the successful solution of the problem depends on a number of causes and factors, among which, first of all, the following should be emphasized: (1) the existence of valid legal acts inherited from the Soviet times (in accordance with the principles of succession), and the need to revise and update such acts according to the modern Ukrainian agenda as an independent national state; (2) the need to bring the legislation in line with the objective conditions of social development; (3) adoption of a significant number of new legislative acts and the need to bring them into a unified operational system; (4) Ukraine's recognition by the international community (as a full-fledged subject of international relations), which is connected with the task of updating the national legislation in accordance with the principles of international law. Dovzhenko suggests that a clear conceptual framework of the structure of Ukrainian legislation will contribute to solving these problems. (Dovzhenko, 2014, p. 14)

Many Ukrainian and international political and state figures, leading theorists and practitioners express their opinions on the ways of a state's legal development. For example, Parkhomenko (2012) argues that the legal system as a part of a system of legislation ensures the development and functioning of the following elements: legal principles, a system of law, legal activity, legal relations, etc. Thus, Parkhomenko (2012, p. 291) writes that the quality and stability of legislation together with its successful implementation determines the degree of development and functioning of the legal system of a particular state.

We agree with Podkovenko's (2005) view that the intensive development of modern social relations requires effective and qualitative legal regulation. The scholar also insists that the optimization of the judicial reform process in Ukraine should uphold the proclaimed principles of a law-governed state, where a person, his rights and freedoms are the highest social value. Obviously, according to the scholar, besides various achievements, Ukraine faces many unsolved state-building and legal problems that require urgent legislative solutions. (Podkovenko, 2005, p. 40) 
We also support Prof. Dashkovska's position on the subject matter (2013) when she argues that the essence of public power in a democratic state lies within the fact that the only source of power is the people exercizing it directly and through the state bodies, as well as municipal bodies. Dashkovska emphasizes that such exercise of power is impossible without the use of acts of state authorities, municipal entities, and their officials, which act as representatives of power. Public officials and state bodies make the decisions that regulate certain social relations to achieve the relevant social and, in particular, legal goals. Such a system of acts of a normative nature is called legislation in legal science and practice. (Dashkovska, 2013, p. 34)

Despite the remarkable amount of legislative framework, and a large number of normative-legal acts adopted by various bodies of public power, the problems of scientific understanding of the formation of the system, as well as the definition of the structure of legislation are still relevant research topics. Problems of theoretical and legal understanding of law and legislation were addressed by such respected scholars of various backgrounds as M. Abdulaiev, S. Alieksieiev, S. Bobrovnyk, A. Zaiets, V. Kozlov, M. Koziubra, A. Kolodii, V. Korniienko, N. Parkhomenko, P. Rabinovych, O. Skakun, O. Skrypniuk, M. Tsvik, and others.

\section{The main theoretical and methodological foundations of the research}

In the fundamental branches of jurisprudence such as general theory of law and constitutional law, such concepts as 'law', 'legislation', and 'system of legislation' have no unambiguous interpretation. In particular, encyclopedic sources provide the following definition of the concept of 'legislation': legislation is a system of normative acts (or laws) that regulates social relations (Koziubra, 2011, p. 499). Some scholars argue that legislation is a system of interconnected normative legal acts of higher legal force, including the Constitution, constitutional laws and laws (Kolodii, 1998, p. 20). There is an opinion that legislation should be understood as a system of all state-regulated laws, as well as international treaties ratified by the parliament (Kolodii, 1998, p. 20). At the same time, it is not necessary for such normative acts to take the form of law. The main thing is that they are recognized as such, which have the force of law in the Constitution (Korniienko, 2011, pp. 402, 403).

The lack of a clear terminological framework often results in contradictory interpretation of legislative matters by bodies and officials of public power. We 
suggest following the well-established practice of using the term 'legislation' to denote a combination of laws and regulations. In the internationally accepted practice of rule-making, the term 'current legislation' refers to the whole set of normative legal acts in force in the state.

The terminological confusion mentioned above led to the adoption of the Decision of the Constitutional Court of Ukraine no. 12-pp/98 of July 9, 1998 'The case on the interpretation of the term "legislation".

The Decision states that 'legislation' should be understood as a set of laws and other normative legal acts which regulate one or another area of social relations and act as sources of a certain area of law. The Constitution of Ukraine (Articles 9, 19, 118, para. 12 of the Transitional Provisions) employs this term without providing its definition. Depending on the importance and specificity of regulated social relations, Ukrainian laws apply the term in different meanings: as laws, as laws and legislation, as both laws and other acts of the Verkhovna Rada of Ukraine, as well as acts of the President of Ukraine, the Cabinet of Ministers of Ukraine, and in some cases also the normative acts of central executive bodies (Constitution of Ukraine, Articles 9, 19, 118, para. 12 of the Transitional Provisions).

We believe that the abovementioned Decision of the Constitutional Court of Ukraine emphasized the existence of two main approaches to the interpretation of the term 'legislation': 1) a "narrow" one, according to which the term 'legislation' is identified as 'law'; 2) a "broad" one, according to which the term includes laws, existing international treaties, parliamentary legislative acts, subordinate normative acts adopted within the limits of powers and in accordance with the constitution and laws.

In our opinion, Kashanina (2013), in her monograph, offers an explanation of contradicting issues in the study of law. In the chapter devoted to the concept of legislation, the scholar writes about three approaches to the definition of the idea of legislation. The first approach defines legislation as a set of laws. Such terminological narrowing is more productive than a broader understanding of the term. Kashanina argues that the broad definition should be abandoned since only the law possesses the higher legal force, based on and for which all other normative acts are adopted. According to the second point of view, legislation is a set of normative-legal acts issued by federal authorities (in a federal state) (Kashanina, 2013). The advocates of the third point of view believe that legislation is a set of all valid normative acts in the country (both federal and regional) (Poliakov, 2003, pp. 362, 363). 
The abovementioned debate illustrates the turmoil in the legal field and describes difficulties in defining the concept of 'legislation', the characteristics of the system of legislation, as well as determining the structure of the latter in terms of the territorial structure of the state.

An interesting, although complex definition of the concept of legislation as a system has been proposed by Poliakov (2003), who argues that legislation is a system of objectified textural rules, which, in the process of interpretation and legitimation, act as a source of legal norms. Thus, Poliakov emphasizes, legislation is a sign system which is expressed mainly as text, which serves as a basis for justifying the existence of legal norms. The structure of the legislation, in contrast to the system of rules of law, is "material", since it consists of textually canonized written normative-legal acts that are "voluntarily" united in the field of legislation. It also includes legal acts and the whole scope of the legislation, which "do not fit" into the recognized branches of law (Zahalna teoriia derzhavy i prava, 2009, p. 720).

In our opinion, when characterizing the legislation as one of the elements of shaping the law, the instrument of social and legal regulation, as well as the result of law-making activity of various actors, including bodies and officials of local self-government, it is necessary to use the previously named second, so-called "broader" approach to its interpretation. However, this further complicates the definition of the place and role of acts of local self-government in the system of national legislation.

\section{The characteristics of local self-government legal acts}

Different scientific sources distinguish between the same characteristic features of the system of legislation. These usually include the following: (1) the system of legislation is an element of the legal system; (2) the system of legislation has a hierarchical (vertical) structure, that is the location of legal acts in it depends on their legal force; (3) the system of legislation has a horizontal structure, which forms its branches in accordance with the subject of legal regulation; (4) the system of legislation is characterized by integrity, systematic, unified direction of all normative legal acts, their hierarchical ties; (5) the system of legislation is of an integrative nature, that is, at the same time, is the source of law, as well as the form of its existence.

It can be argued that the system of legislation is multidimensional. The idea 
that this system includes horizontal and vertical measurements is leading in science. The horizontal structure of a system of legislation is most closely related to the structure of a legal system. The concept of a 'system of law' and a 'system of legislation' are correlated respectively as content and form. Thus, the horizontal structure of the system of legislation includes: (1) legal norms; (2) normative-legal acts; (3) legal institutes; and (4) branches of legislation. The vertical structure of the system of legislation is manifested on the vertical plane, which is expressed in the hierarchical construction of normative legal acts, in their subordinate ties.

The identification of the hierarchy of normative-legal acts that compose the system of national legislation (in the absence of a transparent legal and regulatory settlement of this issue) is possible only through the analysis of certain constitutional and legal norms and is also based on the provisions of domestic legal science, in particular, achievements in the field of the theory of state and law, constitutional law, municipal law, etc. To solve this problem, it is necessary to define the place of a body of public power in the mechanism of the state and the system of public power bodies, as well as to identify the nature, scope, and limits of its competence.

Traditionally, depending on the legal force of normative-legal acts, a vertical (hierarchical) structure of national legislation can be defined, which includes (domestically): (1) the Constitution of Ukraine, which has a higher legal force and is the basis of legislation; (2) laws and codes, the main purpose of which is to provide an integrated, comprehensive and holistic solution to certain problems of social and economic development of the society; (3) normative decrees and orders of the President of Ukraine, issued in accordance with the Constitution of Ukraine; (4) sub-normative legal acts of central executive bodies of power; (5) acts of local executive bodies; (6) acts of local self-government bodies issued in accordance with the execution of delegated state powers (Rabinovych, 2005, p. 266).

Thus, normative-legal acts of local self-government, as a rule, are located at the lower level of the system of national legislation. They represent the lower structural unit (element of the system of law).

In the monograph mentioned above devoted to the issues of the modern structure and characteristics of law, Kashanina (2013) offers interesting thoughts and provides striking examples of the overlapping of local normative-legal acts at the municipal level. The scholar writes that the legal status of normative acts of the municipal bodies is quite problematic (Kashanina, 2013). According to the 
Constitution, the municipal bodies are not part of the system of state bodies of power because they are only responsible for local issues. However, they can be given separate state powers to be implemented under the control and supervision of the state. In the course of its activities, municipal self-government bodies are therefore forced to issue normative acts. It suggests that de facto their normative acts are mandatory, thus supporting the argument for including the acts of local self-government in the system of legislation. According to Kashanina (2013), such insignificant normative inclusions are unlikely to violate the general picture of legislative norms.

Reflecting on the legal properties of acts of local self-government, Bondar (2003) writes about the correlation of state-power and non-state principles in the content of the municipal-legal norms. The author draws attention to the fact that a large number of sources of municipal law are adopted at the level of federal and regional bodies of power in the form of normative-legal acts (laws). The norms of municipal law contained in the latter are substantially state power orders as they come from the state and they also presuppose the possibility of using state coercion. At the same time, Bondar states that the sources of municipal law are normative-legal acts of local self-government. Such acts issue orders that cannot be considered state power but are of a public-power nature as they emanate from the municipal power. (Bondar, 2003, p. 168)

Exploring normative-legal acts, Alieksieiev (2008) offers an interesting classification: (1) laws; (2) decrees; (3) acts of local authorities; (4) acts of state administration. Why has the scholar excluded the normative-legal acts of local self-government from the list, remains unexplained. However, Alieksieiev (2008) admits that his classification (based on the specified criterion) is not accurate, complete and consistent.

Alieksieiev (2008) claims that accurate classification is not possible because the same state body often possesses the competence to adopt normative acts with different legal force. He explains that this classification is not complete because it does not contain all types of normative acts (for example, departmental acts issued by the bodies of justice, supervision, and control, internal organizational acts). Finally, the scholar justifies the inconsistency of classification by the fact that it cannot reflect the legal validity of normative acts (for example, the acts of public administration include general and departmental, and internal organizational acts). (Alieksieiev, 2008, pp. 452, 453)

Unlike Kashanina, Alieksieiev develops the classification of subordination of normative-legal acts including them in the system of legislation. However, 
he excludes the acts of local self-government. So, according to the scholar, the normative-legal acts of local self-government are not part of the national legislation. (Alieksieiev, 2008). In turn, Bondar (2003) does not recognize acts of local self-government as part of the national system of legislation.

In her monograph, Petryshyna (2011) devotes much attention to issues of norm-making activity in local self-government bodies. The author insists that a significant number of sources of municipal law are adopted at the level of central and local government in the form of normative-legal acts. The norms of the municipal law contained in them come from the state and are provided with the possibility of using state coercion. Nevertheless, a large number of sources of municipal law are normative legal acts of local self-government. The peculiarity of the prescriptions contained therein lies in the fact that they, by their very nature, do not belong to the legal norms coming from the state in the face of its law-making bodies. (Petryshyna, 2011)

The rules of conduct contained in the normative legal acts of local selfgovernment, although not issued by the state, however, have a public-power nature, since they are adopted by the municipal power bodies. The latter is an expression of the power of the people, one of the fundamentals of the constitutional system. Therefore, in the legal norms of these acts, there is not only the 'power of authority' of local self-government but also the 'authority of the municipal power' as a special public power, which is in a single system of democracy (Petryshyna, 2011).

In her study on legal acts of bodies and local self-governmental officials in the system of sources of municipal law of Ukraine, Naumova (2017) argues that when including these acts into the hierarchical system of legislation of Ukraine they should be placed lower than the subordinate acts of the legislative branch of power, as well as central and local executive bodies. Naumova also writes about legal mistakes due to the ignorance of the nature of the power of bodies and local self-government officials. According to the author, the municipal power is a state-guaranteed right given to the regional community independently or via local self-government bodies and officials to resolve issues of local importance within the Constitution and laws of Ukraine. The scholar points at the subordinate nature of the activities of bodies and officials of local self-government; however, she does not refer to their subordination to the vertical of the executive branch (Naumova, 2017). Thus, Naumova arrives at the conclusion that acts of local self-government (municipal acts), along with the Constitution and laws of Ukraine, relevant international legal instruments, decrees of the President of Ukraine and resolutions of the Cabinet of Ministers 
of Ukraine, form an independent subsystem of subordinate normative acts in Ukraine (Naumova, 2017, p. 106).

While investigating the acts of local self-government to determine their specifics, Kuznietsov (2011) distinguishes between such concepts as 'acts of local self-government', 'acts of bodies and officials of local self-government', 'normative-legal acts of bodies and officials of local self-government'. He concludes that the bodies of local self-government carry out activities and issue normative-legal acts by carrying out the similar law-making activity. Therefore, the author automatically includes relevant acts in the system of law. At the same time, Kuznietsov (2011) concludes that the normative-legal acts of local selfgovernment bodies are part of the national legislation as the author includes them in the list of normative-legal acts that are subject to state registration (their inclusion in the Unified State Register of Legal Acts).

However none of the documents regulating the implementation, the procedure for keeping the Register, the procedure for submitting normative-legal acts for state registration, show any indications of regulatory acts of local selfgovernment (Resolution of the Cabinet of Ministers of Ukraine, no. 731; Order of the Ministry of Justice of Ukraine, no. 34/5). We support Pashchenko (2015), who claims that the legislation system consists not only of the provisions of the existing national legislation but also of normative-legal agreements, it can be argued that the international treaties signed on behalf of Ukraine are part of the domestic legal system, even if the Verkhovna Rada of Ukraine does not yet ratify them. At the same time, the scholar writes that international agreements become part of the legal system only after ratification (Pashchenko, 2015, p. 76).

As we noted above, the hierarchy of normative-legal acts within a system of national legislation requires a comprehensive analysis of constitutional and statutory norms. It should also take into account scientific developments, in particular, achievements in the field of the theory of state and law, constitutional law, administrative law, municipal law, etc. Indeed, it is necessary to define the place of public power in the mechanism of the state and the system of public power, as well as to establish its limits and competences.

So, in our opinion, there are direct connections between the nature of local self-government, the relation of local self-government to state administration, state power and municipal power. Consequently, it is about a conceptual component - a modern understanding of the notion of local self-government, as well as the form of its expression (consolidation) - a set of relevant normativelegal acts and other sources of municipal law. 
In this context, one of the leading experts in the field of local self-government, Serohina (2016) notes that the mechanism of public power itself is a holistic, systematic, multilevel concept embracing all forms of direct democracy, the totality of state and municipal bodies. The author insists that in modern society, no matter how developed institutions of elections, referendums or other forms of direct democracy are, the leading role in the implementation of management belongs to the state apparatus and the system of local self-government bodies. As two subsystems of public power are connected, any significant changes in the state apparatus should also be reflected in the order of local self-government to ensure consistency. (Serohina, 2016, p. 145)

We agree with the conclusion about the significance of local self-government for the development of modern society and a democratic rule of law. We believe that the recent Ukrainian reforms illustrate the interest of governmental officials, politicians, active citizens, and the whole society in the structural changes on the level public administration, including the branch of local self-government.

There is also a significant interest of researchers towards the nature and essence of the municipal power. And their results, in particular, in the form of proposals and drafts of relevant changes and new normative-legal acts in the field of local self-government testifies to the real existence and development of the relevant branch of law, and also of a number of interconnected and interdependent normative-legal acts and individual norms that regulate certain types of relationship in local communities.

\section{The place and the role of local self-government normative-legal acts in the system of national legislation}

In our opinion, while identifying the correlation of normative-legal acts of local self-government with other normative-legal acts to determine their place in the system of national legislation, it is necessary to take into account the peculiarities of local self-government and municipal power in general.

The national constitutional model of local self-government demonstrates different aspects and dimensions of this phenomenon. First and foremost, local self-government is an institution of the civil society, a valid form of selforganization of people, a movement towards human solidarity. Batanov (2010) underlines clear intentions to define a democratic way of development for Ukraine as the primary principle of a political system based on universal values. 
He reiterates state obligation to citizens to provide an appropriate range of civil powers, to ensure their public and legal protection (Batanov, 2010, p. 183).

Based on the analysis of the provisions of Article 140 of the Constitution of Ukraine, one can conclude that the right to local self-government is a natural right of a territorial community, which, moreover, is an integral part of the system of natural law. Therefore, with the help of legal measures, the state, represented by its bodies and officials, only supervises the self-governing activity of territorial communities.

Besides, local self-government is defined in the constitutional legal documents as an institute of human and civil rights and freedoms. It represents the right of the territorial community to resolve issues of local importance independently. The approach fits into the system of human rights of citizens in a democratic society and the state.

Also, based on democratic institutions and taking into account academic achievements, local self-government is an element of institutes of constitutional order. Thus, based on the generally recognized principles of organization and activity of local democracy, local self-government as a manifestation of the power of the people is one of the fundamental principles of the constitutional system of Ukraine. It is supported by the provisions of the Constitution, which establish the foundations of the legal system (in particular, Articles 1, 3, 5, 6, and 7).

In this context, Articles 7 and 140-146 of the Constitution of Ukraine are of particular significance, as well as relevant provisions of the current legislation, including the applicable Law of Ukraine 'On local self-government in Ukraine'. Thus, the analysis of the above requirements shows that local self-government is more than one of the institutes of the constitutional system. The Constitution of Ukraine and European Charter on Local Self-Government (1985) reinforce the recognition of the organizational, legal and financial autonomy of local selfgovernment.

The European Charter on Local Self-Government establishes the obligation of the participating states to recognize the principle of local self-government in national legislation, as well as the necessity and importance of ensuring organizational, legal and material financial guarantees for its implementation. The Charter establishes the preconditions for law-making, normative, lawenforcement and right-realization activities.

This correlates with the provisions of Articles 6 and 7 of the Constitution of Ukraine, according to the analysis of which (and also taking into account 
the relevant decisions of the Constitutional Court) local self-government is recognized by the state as an independent level of power exercized by the people. Consequently, along with the recognition of the principle of the division of public power into branches, the Constitution recognizes the existence of such a subsystem of public power as the municipal power, which is implemented through the institutions of local self-government. This subsystem exists along with the subsystem of state power, which indicates the absence of hierarchical links between them.

At the same time, it is important to understand that this does not mean the complete autonomy of the municipal power and institutions of local selfgovernment from the state since all subsystems and public power bodies form the unified public administration mechanism. Also, one should take into account the fact that local self-government bodies execute a number of powers delegated by the state, which means they are controlled by the relevant bodies of state executive power. However, control by the state bodies of power should not lead to interference with the activities of local self-government bodies in the sphere of exercizing their own powers. In turn, the exclusiveness and completeness of the powers of local self-government bodies are primarily aimed at limiting the possibility of their duplication between executive bodies of local selfgovernment and state executive bodies, as well as between different levels of local self-government bodies (the negative manifestation of such duplication may be the contention of competence, conflicts between different institutions, "dispersion" of responsibility, etc.) (Petryshyna, 2016, pp. 12, 14).

Thus, the constitutional separation of state power and local self-government points to the objective existence of two forms of the exercise of public power in Ukraine - state and self-government (municipal), for which there are common features as well as different ones, in particular, specific, subjective-object and functional characteristics, the study of which reveals their content and essence (Naumova, 2017, p. 12).

The features of the municipal power that distinguish it from the state include: (1) a specific carrier (subject of power); (2) the local-territorial character of the authority; (3) realization of municipal power through the institutions of local self-government; (4) a particular sphere of realization of the municipal power and, accordingly, the process of development of local legal acts; and (5) organizational, legal, material and financial isolation (autonomy) of the municipal power from the state power. 
In our opinion, the municipal power should not be completely opposed to the state. After all, the direction of the activities of both the state and local selfgovernment bodies is determined by the rights and freedoms of human and citizen. First of all, it is a question of the rule of law and its relation to the principle of legality.

Our study was driven by a goal to find out the underlining concept of the origin of local self-government and its justification, which, in our opinion, most fully and accurately reflects the essence and content of local self-government. Considering the abovementioned aspects, it is possible to draw a conclusion on the so-called dual nature of local self-government, which manifests itself both in the presence of the public-power component and the public basics.

It seems that this position was underpinned in the provisions of the current legislation, taking into account the wording: "recognized and guaranteed"; "the right of a territorial community"; "the right and real ability guaranteed by the state"; "have the power to adopt normative and other acts in the form of decisions", and others. At the same time, being on the one hand natural law, and on the other - a public institution of power, with the help of which the will of the members of territorial community is objectified by the bodies and officials of local self-government, have the right to resolve issues of local importance, including by adopting normative-legal acts. Normative-legal acts, which are adopted by their bodies and officials, may also be adopted in the framework of the exercise of the delegated (state) powers.

Therefore, it is possible to state the recognition and guarantee by the state of the right of bodies and officials of local self-government to resolve issues of local importance on behalf and in the interests of the territorial community within the limits of the Constitution and laws of Ukraine under its own responsibility. It is a question of the existence of primary normative competence - the right to adopt normative-legal acts to resolve issues of local importance, mostly within their own and/or exclusive powers of these bodies arising from the peculiarities of their nature.

Moreover, one should pay attention to the fact that today the legislation enhances the possibilities of local self-government: by defining the powers of its bodies and officials; by separating them from the powers of the state (in the person of its bodies and officials); by extending of the normative competence of the local self-government (including in the future, which can be reflected in the relevant changes and additions, as well as in the concepts of reforms, plans and development programs); by defining the legal nature of normative-legal 
acts of local self-government in the national legal system; by recognizing the possibility of judicial protection, in particular, the right to be a plaintiff (Art. $18^{1}$ of the Law of Ukraine 'On local self-government in Ukraine') and so on.

At the same time, taking into account both constitutional and legal regulation and the real state of affairs, even the most developed and democratic states of the world cannot completely abandon the practice of delegation of powers from bodies of state power to local self-government bodies (for example, in the United Kingdom the relevant authorities can authorize the adoption of a certain a normative-legal act, in Germany normative-legal acts of local self-government on the issues of their delegated powers are regularly adopted and implemented) Thus, we can speak of the existence of so-called practice of "sanctioned rulemaking".

The activities of both the state and local self-government bodies are determined by the rule-of-law principle (Art. 8 of the Constitution of Ukraine). The principle presupposes the subordination of the state and municipal power, their institutions to human rights, the recognition of the priority of the right in any positive activity of public authorities (including the development and adoption of normative-legal acts of local self-government; see Constitution of Ukraine, 2011).

Thus, Ukrainian legal experts continue to discuss the principle of the rule of law. Such conversations are productive as long as they grow around fundamentals and conditions for its realization: the priority of human rights, the conformity of the normative-legal acts to the law ("domination of legal laws"), legal certainty and the limitation of state and municipal power by law (European Commission "Democracy through Law", Venice Commission).

The priority of human rights involves the recognition of human rights and freedoms with the highest social value. The principle of the rule of law should guarantee the inalienable rights of a person and citizen to freedom, equality, respect for human honor and dignity. Therefore, normative activity should be carried out with strict observance of this principle. The drafting and adoption of normative-legal acts (including normative-legal acts of local self-government) should ensure and protect the inalienable rights of citizens.

The limitation of state and municipal power by the law means that freedom in society is possible only under conditions when public power is restricted to and is under control of the law, as well as when public power interacting with civil society within limits defined by law. 
In turn, legal certainty is a condition by which citizens have the opportunity to anticipate the consequences of their actions, which follow from their consolidation in the texts of normative-legal acts. Compliance with the rulemaking subject of clear rules regarding the form and content of normative-legal acts serves as a guarantee of their implementation. Conversely, non-compliance with the requirements regarding the form and content of such acts may lead to their recognition as unconstitutional and therefore ineffective (Constitution of Ukraine, 2011).

The compliance of the normative act with the law (or "domination of legal acts") implies compliance with the constitutional requirement of the legal nature of the normative-legal acts, which means that the law "reflects" (as provided for by the Constitution) human rights "in full", as well as the direct effect of such a normative-legal act. The narrowing or restriction of human rights in a normative-legal act entails its illegal and unconstitutional nature and is subject to consideration by the Constitutional Court to establish its conformity with the Constitution of Ukraine. Such actions may indicate the ignorance of human rights and mean the denying of the law and its supremacy in rule-making activities.

Local self-government normative-legal acts, along with other normative-legal acts, are often characterized as by-laws. First of all, the fact is that despite the existence of a separate subsystem of public power-the municipal power, as well as the independence of local self-government institutions, legal, organizational, material and financial independence are determined by the Constitution and laws of Ukraine. Consequently, the peculiarities of the existence of a territorial community (hromada), as well as the establishment and functioning of local self-government bodies and officials, which are determined by the charter of a territorial community, by regulations of a local council (radas), by the other bodies' provisions, are primarily determined at the level of laws. Therefore, the normative-legal acts of local self-government must comply with the Constitution and laws of Ukraine, based on the principle of legality.

Given the fact that, on the one hand, hierarchical subordination between state power and local self-government does not exist, and, on the other hand, that the latter is a part of a single system of public authority in the state, it should be stated that the normative-legal acts of local self-government, as well as other subordinate legal acts, cannot contradict the laws of Ukraine, should be aimed at their implementation, regardless of whether it is a question of resolving issues of local importance or the execution of delegated by the state powers. 
At the same time, in our opinion, the system of local self-government normativelegal acts is relatively conditional located at the lower level of the system of national legislation. After all, given the peculiarities of the municipal selfgovernment, the subordination between the latter and the bodies of state power in a democratically organized society cannot exist. That is, the system of local self-government bodies is not part of the hierarchical structure of the state power system. Instead, control over the activities of local self-government bodies can only affect the issue of the legality of the acts of local self-government bodies and officials, as well as the execution of the powers delegated by the bodies of state power.

Also, such a feature of local self-government system should be mentioned as the absence of subordinate links in it. That is, it can only be about the nature of the local self-government and its bodies, and not about their subordination. Taking into account the above, it can be argued that the system of legal acts of a specific territorial community is presented by two elements: the normative-legal acts of representative bodies of local self-government (radas) and regulatory acts of other local self-government bodies (primarily, executive and regulatory bodies).

So, at present, the system of normative-legal acts of local self-government as a phenomenon of reality is at the initial stage of formation. Using this wording, we seek to emphasize the fact that local self-government in Ukraine is still in the transformational phase of its existence and is constantly faced with barriers to asserting its genuine effectiveness and efficiency. Also, one should take into account the fact that in each administrative-territorial unit, each territorial community, through its activities (first of all its bodies and officials) form their own system of acts, which includes the normative and other acts of local selfgovernment.

\section{Conclusions}

Thus, taking into account the nature of the municipal power and local selfgovernment, especially their relationship with the state power, as well as the peculiarities of the structure and functioning of the system of state power bodies, local self-government, the structure and links of elements of the legislative system, we believe that the following conclusions can be drawn:

1. The system of legal acts of local self-government-a unified system of legal acts of the respective administrative-territorial unit, a territorial community and includes acts of normative-legal and others. 
2. The system of normative-legal acts of local self-government is the result of the activity of a separate subsystem of public power-the municipal power, which is implemented through the institutions of local self-government.

3. The system of normative-legal acts of local self-government is represented by two components (taking into account the number of such acts and also the absence of mechanism of realization of the right of territorial community to make decision (including a form of a normative-legal act) on their own): (a) regulatory acts of local self-government, which come from representative bodies of local self-government and (b) normative acts coming from other local self-government bodies.

4. The system of normative-legal acts of local self-government is an integral part of the structure of the system of the national legislation of Ukraine.

5. The system of legal acts of local self-government is a separate sub-system of normative-legal acts of local self-government which can be characterized as by-laws.

It is also worth mentioning that the path from the Soviet ideas and postulates to the European values (and the EU) in the context of local self-government and its normative-legal activity should be projected through the prism of interaction between the state, local self-government bodies and the community, as the latter two are still distanced from each other, which demonstrates the more profound problems of the state and civil society, the root of which is exactly the "Soviet building" doctrine, which founded this particular system, so ill-suited to reform and so resilient.

At the same time, in regard to the ongoing decentralization reform mentioned at the beginning, we can highlight a number of general recommendations aimed at the local level but implemented not only by local self-government bodies but also by state authorities (and supported by the community) that are related to the problem of establishing the substance, role and place of acts of local selfgovernment in the legal system of Ukraine. These are, as follows:

1. The development at the legislative level of a national system of monitoring and professional evaluation of state policy, programs and projects in Ukraine, which would provide for the establishment of national standards of evaluation, the procedure for its implementation, dissemination and use of results, the creation of appropriate legal, organizational and resource support for evaluation mechanisms.

2. The promotion of the development of municipal management, the urge to increase the level of professional competence of local self-government officials and deputies of local councils using the best domestic and 
European practices (although such programmes are already in place, the impact of their implementation is still too insignificant to be taken into account).

3. The improvement of the content, forms, methods, and ways of training of local self-government officials in order to provide local self-government with modern managerial personnel.

4. The modernization of professional programs aimed at training and professional development of specialists in the field of local selfgovernment. This and the previous two points are conceptually important in the context of the discussed problem, as the transfer of the necessary tools from the state to the local self-government is not enough in itself (the decentralization reform has demonstrated that often local self-government officials and deputies are unable to effectively use the legal and financial opportunities provided within the framework of the reform).

Oleh Petryshyn, Candidate of Legal Sciences, is an assistant at the Department of the EU Law of Yaroslav Mudryi National Law University, scientific secretary at the Scientific Research Institute of State Building and Local Government of the National Academy of Legal Sciences of Ukraine. Petryshyn's scientific interests include Ukraine's EU cooperation and integration policies, state building, and human rights.

Maryna Petryshyna, Candidate of Legal Sciences, is a docent and associate professor at the Department of State Building of the Yaroslav Mudryi National Law University, senior research Officer at Scientific Research Institute of Legal Provision of Innovative Activity of National Academy of Legal Sciences of Ukraine. Maryna Petryshyna's sphere of scientific interests include local self-government, municipal power, local self-government rule-making, normative-legal acts of local self-government, innovative activity of local selfgovernment bodies and officials, etc.

Oleh Hyliaka, Candidate of Legal Sciences, is head of the Department of Planning and Coordination of Legal Studies in Ukraine, National Academy of Legal Sciences of Ukraine. Ole Hyliaka's scientific interests include human rights, general theory of law, constitutional law, law of the European Union, and practices of the European Court of Human Rights.

Prof. Taras Didych, LLD, is a professor at the Department of Theory of Law and State, Law Faculty of the Taras Shevchenko National University of Kyiv. Didych's scientific interests include theoretical and methodological foundations of law-formation, law-making, normmaking, formalization of law, socialization of law, factors of law-formation, subjects of lawformation. Prof. Didych is the author of more than 100 scientific and practical publications in the field of law-making, problems of normative design, and legislative technique of Ukraine. 
For more than twelve years Prof. Didych has been involved in drafting laws in Ukraine, Kazakhstan, and Poland (more than 80 drafts prepared, 34 of which were passed).

\section{References}

Abdullaev, N. D. (1972), Dyalektyka pravotvorchestva [Dialectics of law-making], Baku: Azerneshr.

Aleksieiev, S. S. (2002), Voskhozhdenye k pravu: Poysky y reshenyia [Ascent to the law: searches and decisions], 2nd ed., Moscow: NORMA.

Aleksieiev, S. S. (2008), Obshchaia teoriya prava: uchebnyk [The general theory of law: a textbook], 2nd ed., Moscow: TK Velby; Yzd-vo Prospekt.

Batanov, O. V. (2010), Munitsypalna vlada v Ukraini: problemy teorii ta praktyky: monohrafiia [Municipal authorities in Ukraine: problems of theory and practice: monograph], Kyiv: Vyd-vo "Iurydychna dumka".

Bobrovnyk, S. V. (2004), 'Harantii zakonnosti yak neobkhidna umova rozvytku ta nesuperechlyvosti zakonodavstva' [Guarantees of legality as a necessary condition for the development and non-compliance of legislation], in Zakonnist: teoretykopravovi problemy doslidzhennia ta vprovadzhennia, Kyiv, pp. 29-31.

Bondar, N. S. (2003), Munitsipalnoe pravo Rossiiskoi Federatsii [Municipal Law of the Russian Federation], Moscow: Yunyty-Dana.

Constitution of Ukraine (2011), Konstytutsiia Ukrainy: Naukovo-praktychnyi komentar [The Constitution of Ukraine: scientific and practical commentary], Kharkiv: Nats. akad. prav. nauk Ukrainy \& Pravo.

Dashkovska, O. R. (2013), 'Systemnist zakonodavstva yak yoho konstytutyvna oznaka' [The system of legislation as its constitutive feature], Nauk. visn. Mizhnarod. humanitar. un-tu, Seriia: Yurysprudentsiia, vol. 1, no. 6(2), pp. 34-37.

Decision of the Constitutional Court of Ukraine no. 12-rp/98, Rishennia Konstytutsiinoho Sudu Ukrainy № 12-rp/98 (sprava pro tlumachennia terminu 'zakonodavstvo') [(case on the interpretation of the term 'legislation')]. Retrieved from http://zakon. rada.gov.ua/laws/show/v012p710-98 [accessed 24 Apr 2019]

Didych, T. O. (2018), Teoretyko-metodolohichni zasady pravoutvorennia [Theoretical and methodological principles of law-making], Avtoref. dys. d-ra yuryd. nauk: 12.00.01 teoriia ta istoriia derzhavy i prava; istoriia politychnykh i pravovykh uchen, Kyiv: KNU imeni Tarasa Shevchenka.

Dovzhenko, Ye. V. (2014), 'Paradyhma suchasnoho ukrainskoho zakonodavstva' [Paradigm of modern Ukrainian legislation. Our law], Nashe pravo, no. 8, pp. 13-19. 
European Charter of Local Self-Government (1985), Charte européenne de lautonomie locale, Strasbourg, 15.10.1985. Retrieved from http://conventions.coe.int/Treaty/ FR/Treaties/Html/122.htm [accessed 29 Apr 2019]

Hyliaka, O. S. (2015), 'Rol yurydychnoi tekhniky v pidhotovtsi yurydychnykh dokumentiv' [The role of legal technique in the preparation of legal documents], in Yurydychna tekhnika: doktrynalni osnovy ta problemy vykladannia: tezy dop. ta povidoml. uchasnykiv nauk.-prakt. konf., m. Kharkiv, 30 ver.-1 zhovt. 2015, Kharkiv, pp. 83-86.

Kashanina, T. V. (2013), Struktura prava: monografiya [Structure of law: monograph], Moskva: Prospekt.

Kolodii, A. M. (1998), Vykorystannia rozroblenykh u SND modelnykh zakoniv yak zasib vdoskonalennia zakonodavstva Ukrainy. Problemy harmonizatsii zakonodavstva Ukrainy z mizhnarodnym pravom: mater. nauk.-prakt. konf. [Use of model laws developed in the CIS as a means of improving the legislation of Ukraine. Problems of harmonization of Ukrainian legislation with international law: mater. sci. pract. conf. (October 1998)], Kyiv: In-t zak-va Verkhov. Rady Ukrainy, pp. 284-286.

Korniienko, V. V. (2011), 'Vidminni i spilni rysy efektyvnosti prava ta efektyvnosti zakonodavstva' [Distinctive and common features of the effectiveness of law and the effectiveness of legislation], Mytna sprava, no. 4(76), ch. 2, pp. 357-360.

Koziubra, M. (2007), 'Verkhovenstvo prava i Ukraina' [The Rule of Law and Ukraine], Pravo Ukrainy, nos. 1-2, pp. 30-63.

Kozlov, V. A. (1972), Voprosi teoryy effektyvnosty pravovoi normi: avtoref. dyss. ... kand. yuryd. Nauk. [Problems of the theory of the efficiency of the legal norm: author's abstract], Leningrad: Lenynhrad. hos. un-t ym. A. A. Zhdanova, Yuryd. fak-t.

Kuznietsov, A. O. (2011), 'Akty orhaniv ta posadovykh osib mistsevoho samovriaduvannia: teoretychnyi aspekt' [Acts of bodies and officials of local self-government: theoretical aspect], Derzhavne budivnytstvo, no. 1. Retrieved from http://nbuv.gov. ua/UJRN/DeBu_2011_1_25 [accessed 29 Apr 2019]

Naumova, K. I. (2017), Pravovi akty orhaniv $i$ posadovykh osib mistsevoho samovriaduvannia $v$ systemi dzherel munitsypalnoho prava $v$ Ukraini [Legal acts of bodies and officials of local self-government in the system of sources of municipal law in Ukraine], PhD thesis, Kharkiv. Retrieved from http://nauka.nlu. edu.ua/download/diss/Naumova/d_Naumova.pdf [accessed 29 Apr 2019]

Order of the Cabinet of Ministers of Ukraine, no. 333-p, Pro skhvalennia Kontseptsii reformuvannia mistsevoho samovriaduvannia ta terytorialnoi orhanizatsii vlady $v$ Ukraini [On approval of the Concept of reforming local self-government and territorial organization of administration in Ukraine], 1.4.2014. Retrieved from https://zakon.rada.gov.ua/laws/show/333-2014-\%D1\%80 [accessed 5 Sep 2019] 
Order of the Ministry of Justice of Ukraine, no. 34/5, Pro zatverdzhennia Poriadku podannia normatyvno-pravovykh aktiv na derzhavnu reiestratsiiu do Ministerstva yustytsii Ukrainy ta provedennia yikh derzhavnoi reiestratsii: Nakaz Ministerstva yustytsii Ukrainy [On approval of the procedure for submission of regulatory legal acts for state registration to the Ministry of Justice of Ukraine and for their state registration], 12.4.2005. Retrieved from http://zakon.rada.gov.ua/laws/show/ z0742-13 [accessed 29 Apr 2019]

Parkhomenko, N. M. (2012), 'Zakonodavstvo Ukrainy na suchasnomu etapi: kilkisnyi ta yakisnyi analiz' [Legislation of Ukraine at the present stage: quantitative and qualitative analysis], Publichne parvo, vol. 3, no. 7, pp. 291-298.

Parkhomenko, N. M. (2016), Rozvytok zakonodavstva Ukrainy v konteksti konstytutsionalizatsii, yevrointehratsii ta zabezpechennia pravliudyny: monohrafiia [Development of Ukrainian legislation in the context of constitutionalization, European integration and human rights: monograph], Kyiv: In-t derzhavy i prava im. V. M. Koretskoho.

Pashchenko, O. O. (2015), 'Znachennia systemy prava i systemy zakonodavstva dlia z'iasuvannia sotsialnoi obumovlenosti kryminalno-pravovykh norm' [The value of the system of law and the system of legislation to clarify the social conditionality of criminal law], Visn. Asots. krym. prava Ukrainy, vol. 1, no. 4, pp. 71-81.

Petryshyn, O. O. (2014), Pravovi zasady mistsevoho samovriaduvannia varubizhnykh krainakh ta Ukraini: teoretyko-pravovyi ta porivnialnyi analiz [Legal principles of local self-government in foreign countries and Ukraine: theoretical, legal and comparative analysis], Kharkiv: Pravo.

Petryshyna, M. O. (2011), Normotvorcha diialnist $v$ orhanakh mistsevoho samovriaduvannia $v$ Ukraini: monohrafiia [Normative activity in local selfgovernment bodies in Ukraine: monograph], Kharkiv: Pravo.

Petryshyna, M. O. (2016), 'Do proektu Zakonu Ukrainy "Pro vnesennia zmin do deiakykh zakonodavchykh aktiv Ukrainy shchodo zupynennia aktiv orhaniv mistsevoho samovriaduvannia"' [To the Draft Law of Ukraine 'On amendments to certain legislative acts of Ukraine concerning the suspension of acts of local self-government bodies'], Aktualni pytannia publichnoho ta pryvatnoho prava, no. 1, pp. $12-17$.

Podkovenko, T. O. (2005), 'Systema zakonodavstva Ukrainy: stan ta shliakhy vdoskonalennia' [The system of legislation of Ukraine: the state and ways of improvement], Pidpryiemnytstvo, hospodarstvo i parvo, no. 9, pp. 40-44.

Poliakov, A. V. (2003), Obshchaia teoriia prava: Fenomenologo-kommunykativnii pokhod. Kurs lektsii. 2-e yzd. [General theory of law: phenomenologicalcommunicative campaign: Lecture course], 2nd ed., St. Petersburg: Yzd-vo 'Iurydycheskyi tsentr Press'. 
Rabinovych, P. M. (1996), Zakonodavstvo suchasnoi Ukrainy: do kharakterystyky tendentsii rozvytku [Legislation of modern Ukraine: to the characteristics of development trends], no. 7, Kharkiv: Akad. Pravovykh nauk Ukrainy, pp. 14-23.

Rabinovych, P. M. (2001), 'Metodolohiia vitchyznianoho zahalnoteoretychnoho pravoderzhavoznavstva: suchasni tendentsii' [Methodology of the national general theoretical law of the state: modern trends], Biuleten Ministerstva yustytsii Ukrainy, no. 1, pp. 37-45.

Rabinovych, P. M. (2005), Zahalnoteoretychne pravoderzhavoznavstvo: naukoznavchi, metodolohichni ta filosofsko-pravovi problemy. Antolohiia ukrainskoi yurydychnoi dumky [General theoretical law of the state: scientific research, methodological and philosophical and legal problems. Anthology of Ukrainian legal thought], vol. 10, Yurydychna nauka nezalezhnoi Ukrainy, Kyiv: Vyd. Dim “Iuryd. kn.”, pp. 67-81.

Resolution of the Cabinet of Ministers of Ukraine, no. 731, Pro zatverdzhennia Polozhennia pro derzhavnu reiestratsiiu normatyvno-pravovykh aktiv ministerstv ta inshykh orhaniv vykonavchoi vlady [On approval of the Regulation on state registration of legal acts of ministries and other bodies of executive power], 28.12.1992. Retrieved from http://zakon1.rada.gov.ua/laws/show/731-92$\%$ D0\%BF [accessed 29 Apr 2019]

Serohina, S. H. (2016), Reforma mistsevoho samovriaduvannia v Ukraini v suchasnykh umovakh polityko-pravovoho rozvytku. Aktualni problemy derzhavnoho budivnytstva ta mistsevoho samovriaduvannia $v$ konteksti konstytutsiinoi modernizatsii [Reform of local self-government in Ukraine in the current conditions of political and legal development. Actual problems of state building and local self-government in the context of constitutional modernization], Kharkiv, pp. $145-154$.

Skakun, O. F. (2001), Teoriya derzhavy i prava: pidruchnyk [Theory of state and law: a textbook], Kharkiv: Konsum.

Skakun, O. F. (2007), Teoriya gosudarstva i prava (entsiklopedicheskii kurs) [Theory of state and law (encyclopedic course)], Kharkiv: Espada.

Skrypniuk, O. V. (2000), Sotsialna, pravova derzhava v Ukraini: problemy teorii $i$ praktyky. Do 10-richchia nezalezhnosti Ukrainy: monohrafia [Social and legal state in Ukraine: problems of theory and practice. On the 10th anniversary of Ukraine's independence: a monograph], Kyiv: In-t derzhavy i prava im. V. M. Koretskoho NAN Ukrainy.

Tatsii, V. Ya. (2001), 'Znachennia yurydychnoi nauky u formuvanni pravovoi systemy Ukrainy' [The value of legal science in the formation of the legal system of Ukraine], Visn. Akad. prav. nauk Ukrainy, no. 3, pp. 3-22.

Tsvik, M. V. (1968), Zakonnost i pravotvorchestvo. Problemi sotsialysticheskoi zakonnosti na sovremennom etape razvitiia sovetskogo gosudarstva: mezhvuz. 
nauch. konf. [Legitimacy and law-making. Problems of socialist legality at the present stage of development of the Soviet state: interuniversity scientific conf. (Oct. 1968)], Kharkiv, pp. 26-28.

Tsvik, M. V. (1990), Verkhovenstvo zakona v pravovom hosudarstve. Aktualnie problemi formyrovanyia pravovoho hosudarstva: kratkye tez. dokl. y nauch. soobshch. respubl. nauch. konf., 24-26 okt. [The rule of law in a legal state. Actual problems of the formation of a law-governed state: brief abstracts of scientific conf., 24-26 Oct. 1990], Kharkiv, pp. 26-28.

Tsvik, M. V. (2003), Suchasne pravorozuminnia - metodolohichna osnova pravovoi nauky. Metodolohichni problemy pravovoi nauky: mater. mizhnar. nauk. konf. [Modern legal thinking - the methodological basis of legal science], Kharkiv: Pravo, pp. 88-91.

Yevhrafova, Ye. P. (2007), Systema natsionalnoho zakonodavstva v konteksti prava (libertarno-lehistskyi pidkhid) [The system of national legislation in the context of law (libertarian-legal approach)], Kyiv: KNT.

Yurydychna entsyklopediia (1999), [Legal encyclopedia], vol. 2, Kyiv.

Zahalna teoriia derzhavy i prava (2009), [General theory of state and law], Kharkiv: Pravo.

Zaiets, A. P. (1997), 'Svitohliadni osnovy pravo rozuminnia' [The worldview fundamentals of legal thinking], Visn. Akad. prav. nauk Ukrainy, vol. 12, no. 9, pp. 4-9. 